\title{
HHHFNC, HFNC eller nasal høyluftstrømskanyle?
}

\author{
Forkortelser basert på engelske prosedyrebetegnelser bør unngås. Engelske betegnelser bør heller få \\ en god norsk oversettelse. Det vil bidra til at flere forstår hva det dreier seg om.
}

Medisinsk teknologi utvikler seg i høyt tempo, og nye prosedyrer lanseres stadig. Slike prosedyrer får gjerne lange engelskspråklige betegnelser, og disse får ofte raskt innpass i de aktuelle fagmiljøene i Norge. Ofte erstattes de med forkortelser som er uforståelige for folk flest, inkludert leger. Bruken av slike uttrykk og forkortelser kan bidra til å styrke fagmiljøenes identitet, samhold og eksklusivitet - selv om det ikke er tilsiktet - men bidrar ikke til at prosedyrene blir lettere forstått eller mer kjent.

Vi mener at et godt medisinsk fagspråk på norsk bidrar til å lette kommunikasjonen blant leger seg imellom og mellom leger og allmennhet, spesielt pasienter og deres pårørende.

\section{Ny metode for pustestøtte}

Hos premature nyfødte barn har man i mange år benyttet nesekanyler for oksygentilførsel der luftstrømmen av kald, uoppvarmet oksygen ikke kunne økes særlig, da man i så fall ville skade luftveiene. Dette kalles på engelsk ofte «low flow» og regnes strengt tatt ikke som pustestøtte. En ny metode - på engelsk betegnet «high flow nasal cannulae», forkortet HFNC - innebærer at man ved bruk av oppvarmet, fuktet luft kan øke luftstrømmen, med en blanding av oksygen og luft, og dermed gi både oksygentilførsel og pustestøtte (Claus Klingenberg, personlig meddelelse). De mest pirkete vil mene at prosedyren bør kalles «heated humidified high flow nasal cannulae», forkortet HHHFNC.

Da to ferske studier om den nye prosedyren $(1,2)$ skulle omtales i Tidsskriftet, den ene norsk, ble det behov for å få etablert et godt norsk uttrykk til bruk i norsk sammenheng - til erstatning for det engelske «high flow nasal cannulae». Sammen med Claus Klingenberg, førsteforfatter av den norske studien, kom vi frem til uttrykket nasal høyluftstrømskanyle, som fikk støtte også av andre barneleger $(3,4)$.

En svakhet med dette uttrykket er at det ikke fremgår klart at det dreier seg om fuktet, oppvarmet luft. Men det gjør heller

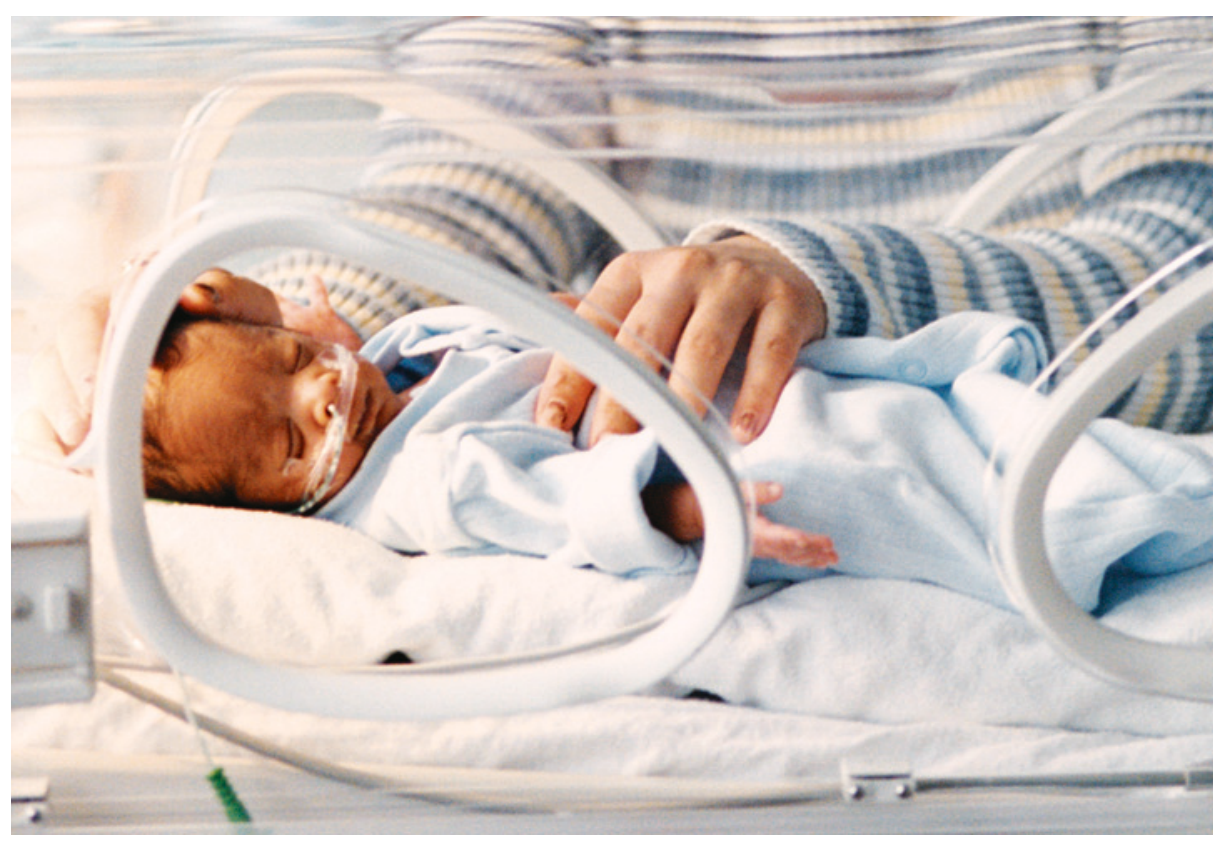

Premature nyfødte kan få pustestøtte med bruk av nasal høyluftstrømskanyle. Foto: Sciencephoto/NTB scanpix

ikke uttrykket som brukes mest på engelsk - «high flow nasal cannulae» (2). Nasal høyfuktighetsvarmluftstrømskanyle er selvfølgelig altfor langt. Sammensatte ord kan ikke deles på norsk, slik man gjør på engelsk.

Vi mener poenget med prosedyren kommer godt frem med uttrykket nasal høyluftstrømskanyle og på en langt bedre måte enn med HFNC-behandling - for ikke å si HHHFNC-behandling.

\section{Petter Gjersvik}

petter.gjersvik@medisin.uio.no

Matilde Risopatron Berg

Tidsskriftet

Petter Gjersvik (f. 1952) er medisinsk redaktør i Tidsskriftet og førsteamanuensis ved Institutt for klinisk medisin, Universitetet i Oslo.

Matilde Risopatron Berg (f. 1985) er assisterende medisinsk redaktør i Tidsskriftet.
Litteratur

1. Klingenberg $C$, Pettersen M, Hansen EA et al. Patient comfort during treatment with heated humidified high flow nasal cannulae versus nasal continuous positive airway pressure: a randomised cross-over trial. Arch Dis Child Fetal Neonatal Ed 2014; 99: F134-7

2. Manley BJ, Owen LS, Doyle LW et al. High-flow nasal cannulae in very preterm infants after extubation. N Engl J Med 2013; 369: 1425-33.

3. Berg MR. En mer skånsom metode for pustestøtte for premature. Tidsskr Nor Legeforen 2014; 134: 283

4. Lindenskov PHH. Bedre pustehjelp til altfor tidlig fødte. Tidsskr Nor Legeforen 2014; 134: 284.

Mottatt 22.12. 2013og godkjent 28.1.2014. Redaktør: Marit Fjellhaug Nylund. 